\title{
Strategy For Strengthening Institutional Capacity of Badan Penanggulangan Bencana Daerah (BPBD) in Garut District
}

\author{
Indra Kristian, Yaya Mulyana \\ Fakultas Pascasarjana Unpas (Email: technician2007@gmail.com, mulyana_yaya@yahoo.com)
}

\begin{abstract}
Indonesia is a disaster-prone area, both due to geological disasters, climate change, and human activities which as a whole require prevention, preparedness, emergency response and recovery as disaster management or disaster management. These activities have been determined by various policies and the establishment of disaster management institutions and organizations. This research is directed at strengthening the institutional capacity of the Regional Disaster Management Agency in Garut Regency which has not been effective Research uses qualitative research methods with organizational case study approaches. Qualitative case study research is a research strategy in which researchers investigate carefully a program, event, activity, process, or group of individuals (Creswell, 2016: 23). The researcher collects complete information by using various procedures for collecting data based on a predetermined time. Research shows that many factors inhibiting the strengthening of BPPD institutional capacity in Garut Regency so that it is not effective are as follows: There is no training on disaster in the BPBD environment, routine training has not been programmed to improve the ability of BPBD employees, salary or wages rely on APBD and there have been delays in salary payments which results in low employee morale. The current recruitment system is only quantity fulfillment, not yet talking about quality. The incentive system is not specifically regulated for organizations that have a high escalation such as BPBD. The personnel is very limited so the BPBD head has difficulty using the personnel. The leader in the BPBD should not be the same as the head of the SKPD in general. Not yet functional staff who can become professionals in carrying out their duties. Therefore, changes in policies and legal regulations are needed, there is no change in policy and legal rules in the face of emergency response conditions. It is also necessary to reform the institutional system carried out at the time of the disaster, before the disaster. To overcome this, several strategic steps are needed.
\end{abstract}

\section{Keywords:}

strategy; strengthening; institutional cashiness

\section{Introduction}

The territory of Indonesia is located in a tropical climate with two seasons, namely heat and rain, with the characteristics of extreme changes in weather, temperature and wind 
direction. Such climatic conditions coupled with the ground surface topography and rock are relatively diverse, both physically and chemically, causing soil becomes fertile. The conditions above can also cause some bad consequences for humans such as hydrometeorological disasters such as floods, landslides, forest fires and drought. Indonesia is aware that disaster issues must be taken seriously since the earthquake and the tsunami that hit Aceh and its surroundings in 2004.

Along with the development of time and increasing human activities, environmental damage tends to get worse and trigger an increase in the number of events and intensity of hydrometeorological disasters (floods, landslides and drought) that occur in turns in many parts of Indonesia.

Indonesia is a disaster-prone area, whether caused by geological disasters, climate change, or human activity which as a whole requires prevention, preparedness, emergency response and recovery as disaster. The activity has been established with various policies and the establishment of disaster management institutions and organizations. Disaster Issue is a very comprehensive and multi-dimensional discussion. Responding to disasters whose frequency continues to increase every year, ideas on disaster management must be understood and implemented by all parties. Institutional is a social form like the organs in the human body that live in the society.

According to Uphoff (1986: 8-9), the terms institutional and organizational are often confusing and interchangeably. Scientifically, social institution and social organization are at the same level, to refer to what we are familiar with social groups, groups, social forms, and others that are relatively similar. However, in recent developments, the term "institutional" is more often used for meaning that encompass both. There are several reasons why people prefer the term. Institutional is preferred because the word "organization" refer to a social form that is formal in nature, and lately tends to get a negative image. The word institutional is also preferred because it gives the impression of being more "social" and more respectful of local culture, or more humanistic.

The concept of institutional arrangement was actually born along with the strengthening of the public desire to reform in various sectors of life including the environment of government bureaucracy. The concept of the arrangement can be interpreted as the setting or arrangement for something to fit the circumstances and needs. The 
government has issued a regulation regarding the formation of organization at the central, provincial and district/city levels in disaster management. Each region is not the same in terms of disaster management depending on the available potential, both in terms of resource budgeting and the characteristics of regions in Indonesia that have their own uniqueness.

The formation of an organization or institution for disaster management has been formed with the existence of laws or government regulations, starting from the central level to the provincial and district/city governments. The approach used is an effective disaster management, quick response and precise. The basic principle is to reduce the risk of material or personnel loss. When a disaster occurs in the BPBD area which is supposed to be a leading Sector in disaster management, it will be constrained because of the echelonization, where the BPBD Chief Executive Officer has the same echelonization as the other Regional Apparatus Organization (OPD) heads. By law, the Regional Secretary is an official of the Head of the Regional Disaster Management Agency, but in the field the Chief Executive of the BPBD has more role, and this will become an obstacle where a leader cannot carry out his duties properly, when the leader has the same rank and authority.

This is consistent with what was stated by Grindle (1997) that the person component plays a role in the institutional strengthening. The weakness in disaster management that have arisen in the past are caused by the overlapping and predicted coordination problems that will recur when disaster strikes.

In connection with that, the focus of this research is directed at strengthening the institutional capacity of the Regional Disaster Management Agency in Garut. While the sub focus is how to keep the institutional capacity of the Regional Disaster Management Agency can run effectively. The ineffectiveness mentioned above will be examined based on the institutional strengthening criteria according to Grindle (1997: 1-28) from the individual side (1) Development of the human resource; (human resource development consists of training, providing salary/wages, the setting of working condition and environment and an appropriate recruitment system); organization (2) Strengthening organization; (organizational strengthening consists of managing incentive systems, utilizing existing personnel, leadership, communication, and managerial structures) and systems (3) Reformation of institution (institutional reform consists of changing the "rules of the game" 
of the existing economic and political system, changing policies and the rule of law, as well as reforming the institutional system that can encourage the strengthening of community participation in disaster management).

Research on institutions or research on disasters has been done a lot, but research on how to strengthen institutional capacity strategies, especially related to institutional disaster, has not been done much. In connection with that, researchers are interested in conducting research with the title: Strategy for Strengthening Institutional Capacity of Badan Penanggulangan Bencana Daerah (BPBD) in Garut District.

\section{Literature Review}

There has been a lot of research related to disaster and also institutional including: Robert Edward Grist for the field of Public Administration and Policy studies submitted on June 19, 2007, at Portlandstate University. In line with the journal above, there is a journal owned by Novia Budi Purwanto entitled "Quantitave Study on Natural Disasters Risk Management Policy, with a focus on how to calculate the disaster risk quantitatively. Another similar journal is "The Changing Paradigm of Emergency Management: Improving Professional Development for the Emergency Manager. Its content focuses on the role of leader in emergency situations (during a disaster). While Windi (2006) wrote about women in disaster management. Chandra Puspita Dewi's article entitled "Study on Policy Issues in Determining Disaster Status, BPBD Institutional, and management of aid after the issuance of Law Number 24 Year 2007,. The above journal discusses macro disasters and nothing specifically about disaster research institutions. The journal above discusses about disasters in macro and nothing specifically about disaster research institutions.

While research on institutions is: Dahlan's writing (2005) titled "Strengthening institutions in waste management (study of increasing Waste Management Officer in Household Waste Management in Pangkalpinang City). Imbaruddin's journal (2013) with the title the capacity of local government agencies in Makassar (Indonesia) to provide services to the public. Ivanovich journal entitled Strengthening institutional strengthening Agropolitan region, there is also research conducted by Jenivia Dwi Ratnasari, Mohammed Makmur and Heru Ribawanto who is a researcher from Universitas Brawijaya Malang who also wrote about Institutional Capacity Development Employment Board Jombang. 
Nasrudin's Research (2010) on Research entitled: The Effect of Institutional Restructuring on the Larasita Program (People's Service for Land Certification) on Improving Service Quality by the Land Office of Bandung City. In line with another study of the journal Yayat Sudrajat, 2017, entitled strengthening the institutional capacity of PKH in realizing a prosperous family in Subang District. Mochamad Chazienul Ulum with the title "Governance and capacity building in disaster management in Indonesia". In particular, case studies on flood prevention caused by the overflow of the Bengawan Solo river. Other research that is in line with the above research is the research on disaster funding conducted by Kurniawati 2013. The strategy for strengthening public organizations was explained by Hilderbrand and Grindle ( 1997 : 37 ) " As organization capacity development refers to the structure, processes and resources of theories organization, and management styles that should be carried out by members of the organization".

Hilderbrand dan Grindle views ( $1997: 46$ ) is that the capacity of institution affected by the objective, how the task, how authority is defined, and how incentives are provided". On the strategy of strengthening the capacity of public organizations that emphasize the role of bureaucracy according to Hilderbrand and Grindle (1997: 47) as follow:

"Shows three dimensions to be considered to assess and evaluate the capacity of public sector organizations. Firstly, the institutional reform which links with system, environmental policies and macro conditionas. Secondly, an organizational strength leads to the division of tasks and functions, thirdly, human resources related to professionalism and capacity of personnel".

Here is the explanation from Hilderbrand and Grindle (1997: 53) regarding the three levels in strengthening the capacity of the organization:

"The capacity in organizational level is concentrated on the organizations performance and culture determining the development of resources.

"At the individual level, identification of capacity focuses on the local human resource management such as recruicment system, effectiveness of training to increase knowledge of personnel, skill and competencies of local public servants in creating good plans and national budgets.

At the system level, the capacity it self works at regulatory or policy framework. This level is addressed on the support of national policy and regulation in ensuring the 
development of human resources (individual aspect) and organizational performance to formulate a good plan and rational budget. Inconducive situation in the system level will impede the ability of bureaucracy to perform well".

All dimensions of strengthening capabilities above are developed as a strategy to realize the values of "good governance". Empowerment of human resources for example, can be seen as a strategy to improve efficiency and effectiveness and maintain moral values and work ethics. The theoretical foundation for the study of Institutional Capacity Building that researchers use is the theory from Grindle because the emphasis of this theory is on human. Where in the explanation Grindle said that:

"Capacity building is the combination of strategy directed to improve efficiency, effectiveness, and responsiveness from the government performance, with attention focused on these dimensions:

(1) Development of the human resource; individual concept

(2) Strengthening organization; and organizational concept

(3) Reformation of institution system concept

The detailed explanation is used as a parameter in the research of the three dimensions. In the context of human resource development: Recruitment, Training, Provision of salary/wages and working conditions and environment settings.

In connection with the strengthening organization, managing the system of incentives, utilization of existing personnel, leadership, communication and managerial structure.

And with regard to reformation of institution, changes in existing systems and institutions, changes in the "rules of the game" of the economic and political system, changes in policy and rule of law, and institutional system reforms.

\section{Research Methods}

This study uses qualitative research methods with an organizational case study approach. Case study qualitative research is a research strategy in which researcher investigates carefully a program, event, activity, process, or group of individuals (Creswell, 2016 : 23). Researchers collect detailed information using a variety of data collection procedures based on a predetermined time. The steps that must be done by researchers in this study are dominantly covered (Rahardjo, 2012: 92-93): Theme selection; Literature 
reading; Formulation of research focus and problems, Data collection; Improvement of data; Data processing; Data analysis; Data analysis process; Theoretical Dialogue; Triangulation of findings (Confirmability); Conclusions of the results of the study; Research report.

In the context of case studies, the most widely used analytical method is content analysis, which describes the material of social events in detail in order to facilitate interpretation in the discussion. According to Bogdan and Taylor (1975: 2) that "Qualitative methods are research procedures that produce descriptive data in the form of written or oral words from people and observable behavior". In this study, dominantly data collection, data analysis and discussion were carried out qualitatively. According to Bogdan and Taylor in Moleong (2007: 4) that "Qualitative methods are research procedures that produce descriptive data in the form of written or oral words from people and observable behavior".

The use of qualitative case study methods with descriptive and exploratory analysis is intended to provide explanations and descriptions based on data and information obtained during the study. Assessment using qualitative methods can also be interpreted as a problem-solving procedure by describing the subject and or object of research based on the facts that appear and try to express the relationship with one another in the aspects being investigated.

\section{Discussion}

The concept of capacity building in general is a set of strategies aimed at increasing the efficiency, effectiveness, and responsiveness of individual, group or organizational performance and systems. It defines what is described by Grindle (1997: 1-28) that:

"Capacity building is the combination of strategy directed to improve efficiency, effectiveness, and responsiveness from the government performance, with attention focused on these dimensions:

(1) Development of the human resource;

(2) Strengthening organization; and

(3) Reformation of institution

From the theory proposed by Grindle above as well as from the results of the study, the researchers describe the strategy regarding strengthening the institutional capacity of the Garut District Disaster Management Agency as follows: 


\subsection{Education And Training In Disaster.}

The skills and knowledge required to occupy certain positions must be possessed by existing employees or human resources. The skills and knowledge can be obtained from education and training. The use of the term education and training in an institution or organization is better known as Diklat (education and training). Organizations that handle employee training are commonly called Pusdiklat (Education and training centers). Education and training can be seen as a form of investment. Therefore, every organization or agency that wants to develop, the training for its employees must receive the most attention. In connection with the disaster training to the staff of the Regional Disaster Management Agency until now has not been implemented. These conditions have an impact on the ability of employees in disaster management to be not optimal.

The first strategy is the human resource planning by realizing employees in the professional BPBD environment because they have been equipped with education and training not only structurally but also training expertise so that in carrying out tasks really on target, on time in accordance with the main tasks and functions owned. With the education and training program, it is expected that employees in carrying out their duties can run and in line with expectations and become professional employees.

The second strategy is to realize the first recruitment of BPBD employees to be accepted as employees who are equipped with expertise suitable for BPBD, of course, expertise on disaster, and the local government conducts education and training or technical training specifically in the field of disaster on a regular basis.

The Third Strategy For technical training that is continuous and integrated, the central government or the provincial government must organize training for one year either centrally or detached, and Garut District may send representatives, although it is still limited.

The Fourth Strategy Garut BPBD organizes training or simulations in the field of disaster involving relevant Regional Work Units (SKPD) and other vertical agencies to organize disaster drills in a coordinated and integrated manner.

The Fifth Strategy Garut BPBD conduct intensive coordination, especially with the TNI in this case Kodim to carry out training posts, where in the TNI organization training posts in disaster management is a unit routine activity in order to implement law number 34 
of 2004 concerning the TNI which separates Military War Operations (OMP) and Military Operations Other Than War (OMSP). In OMSP there is an article that mentions about assisting local governments in disaster management.

\subsection{Granting Salary/Wages}

Institutions need organizations that have effective strategies that must be achieved to achieve success. The leaders and the Human Resources Department can use incentives as a tool to motivate workers to achieve organizational goals. Incentives are defined as a form of payment that is defined as performance. This system is another form of direct compensation outside salary and wages which is a fixed compensation, which is called performance-based compensation (for performance), with the incentive can increase employee motivation to work well. Incentives as motivation that encourage employees to work with optimal abilities, which are intended as extra income outside the salary and wages that have been determined. The provision of incentives is intended to meet the needs of employees and their families.

Incentives can be formulated as adequate remuneration for employees whose performance exceeds the established standards. Incentive is a motivating factor for employees to work better in order to increase employee performance. Mangkunegara (2007: 89) gave the concept of incentives as follows: An award in the form of money given by the leadership of the organization to employees so that they work with high motivation and achievement in achieving organizational goals or in other words, work incentives are giving money outside salaries made by the organization's leader in recognition of work performance and employee contributions to the organization. From the description above, the researchers recommend the following strategies:

The first strategy for giving performance allowance or additional income improvement for BPBD employees should be distinguished from other SKPDs that do not have duties and functions such as BPBD where during holidays with BPBD employees remain subject to disaster preparedness pickets even for female employees and contract workers.

The second strategy is the provision of operational allowance in disaster management activities provided in order to support the main tasks and functions of the BPBD to carry out tasks in the field of disaster management to reduce losses both life, property and other 
losses. Operational allowance should be given in accordance with the activities both in terms of distance, level of risk or time of implementation.

The third strategy is to give a bonus which is an award from the institution if the employee in carrying out the activity is innovating which can shorten the implementation time of the task in the field..

\subsection{Setting Conditions in Disaster Stages.}

Employees are required to understand their respective assignments that have been determined and agreed upon together in the role team. The strategy taken is:

The First Strategy Improving the condition of both the environment or the area affected by the disaster and the recovery of the conditions of the people affected by the disaster in dealing with disasters, quickly and accurately.

The second strategy Arranging the distribution of aid that adjusted to the conditions of an area, meaning that the distribution of aid does not happen in an area that continues to receive assistance, but for other regions that is not at all receiving assistance, this is what we needed for regulation and coordination in the distribution of aid..

The Third Strategy Increasing the role of the BPBD in coordinating various activities for disaster management, areas affected by landslides or erupting volcanoes that difficult to reach conditions usually require a serious treatment.

The Fourth Strategy Given the understanding and comprehension to the society to provide space for officers to carry out their duties, it means that society involvement to participate in helping to deal with disasters is very necessary, not a few people who feel disappointed with the performance of BPBD officers because indeed not all tasks can be carried out perfectly, of course there are deficiencies according to public perception.

The Fifth Strategy Carry out duties in accordance with the existing standard operating procedures. This means that in handling post-disaster, caution is needed in identifying and calculating the amount of loss suffered both property and others.

\subsection{Work Environment in BPBD of Garut District}

The Work Environment in the BPBD of Garut District was explained by the Secretary of the Agency and Head of the Field that the atmosphere of the office environment was relatively conducive because it had just occupied land and a new office in support of work, it's just that for other supporting facilities and infrastructure is inadequate including the 
warehouse where to store goods related to the disaster there is no particular place where ideally the storage of goods/warehouse. From the results of the research that the researchers have described above, the researchers suggest the following strategies:

The First Strategy BPBD prepares warehouses for facilities and infrastructure and separates the consumables from supporting facilities. Based on the results of research and participant observation, researchers still found items that are used in order to support disaster activities placed in an improper place, such as generators that should be placed in warehouse are still placed in office.

The second strategy is as it is known that each employee basically carries their own culture which is carried in the organization and the culture of the organization is a value system that is developed and applies in an organization, as stated by Robbins that organizational culture is a value system carried out by the members organization so as to distinguish these organizations with other organizations.

The Third Strategy is that the Chief Executive continuously carries out and supervises the performance of employees in the BPBD environment for employees who are obedient and dutiful to the provisions will be given rewards. Indeed, at this time the awarding had not yet been carried out, but the chief executive as the holder of the command stick always gave motivation to the employees concerned and continued to be encouraged to continue to excel..

The Fourth Strategy Make communication between leaders and subordinates so that the activities are in line with expectations. Communication is carried out not only between subordinates and leaders but interaction between employees becomes an important factor because each employee has different nature, characteristics and behaviors but if they are incorporated in an organization that become the organizational culture that is characteristic of the organization and this is what distinguishes BPBD from other organizations.

The Fifth Strategy, As the Chief Executive of the BPBD must be willing to listen and pay attention to work complaints and difficulties faced by employees in finding solutions and hold sharing at every opportunity.

4.5. Recruitment System

The strategy that can be implemented in the right recruitment certainly have a minimum target of being a BPBD employee, namely recruiting employees who have 
expertise or professional in the field of disaster or supporting basic tasks related to disaster, meaning that a position cannot be filled by anyone who is not trained and not prepared specifically to do the work. From the description above, the strategies implemented are:

The First Strategy, because BPBD requires employees with special qualifications and competencies at least to understand disaster, recruitment of employees is not based on family relationships and so on, but the quality of employees can be relied on in carrying out tasks and work in the field, disaster management is related to one's life and property that needs to be saved as well as requiring high commitment and dedication to the task, it is very necessary to be associated with wide and spreaded regional conditions..

The second strategy in recruiting employees is to sign an agreement containing commitments from prospective employees, because BPBD requires employees who have commitment and work dedication that is beyond the ability of employees in general. Service that is based on commitment will make employees work more optimally.

The Third Strategy The existing recruitment system should be adjusted to the conditions and needs of the region and the competencies of the employees or prospective employees at Badan Penanggulangan Bencana Daerah. This means that BPBD employees must be people who understand well the area they are responsible for so that when a disaster occurs, the employee can take appropriate and quick actions.

The fourth strategy is the recruitment system carried out through online media by including several requirements that are adjusted to the needs, from the employees of Badan Penanggulangan Bencana Daerah of Garut District. This means that prospective BPBD employees have received clear information from explanations regarding recruitment. So, BPBD employees are chosen employees who are already prepared with all the risks that will be faced and ready to jump in to face all risks in the field.

4.6. Incentive System

Institutions need organizations that have effective strategies that must be achieved to achieve success. The leaders and the Human Resources Department can use incentives as a tool to motivate workers to achieve organizational goals. Incentives are defined as a form of payment that is defined as performance. Incentives in BPBD of Garut so far have not been given, only performance allowance is adjusted to the performance of each employee. Pegawai BPBD employees are regional government employees who have two parent 
organizations, namely the Ministry of Home Affairs if they are regional government employees and they can also be said to be employees of the National Disaster Management Agency. The strategies suggested by researchers are:

The First Strategy is that all BPBD Employees receive special allowances or incentive money that is different from other regional government employees. This will make BPBD employees feel concerned that this will improve the performance of BPBD employees and the vision of BPBD of Garut in disaster risk reduction will be achieved.

The second strategy is when the Disaster Alert is implemented where other employees carry out mass leave, the BPBD staffs who standby are given overtime pay to replace their lost time because they have to carry out the disaster alert.

\subsection{Utilization of Personnel}

Human resources play an active and dominant role in every activity of the organization, because human is a planner, actor, and determinant of the realization of organizational goals, organizational goals may not be realized without the involvement or active role of humans, however advancing equipment or technology owned by the organization will not be of any use if human resources not play an active role. Managing human resources in an office requires competent abilities and skills because humans have different intellect, feelings, desires and backgrounds, so employees are not fully regulated and controlled.

The function of human resources based on the description illustrates that each employee essentially performs two functions, namely the managerial function of carrying out work activities with thought and then operational functions where activities are carried out well, the managerial function consists of planning, organizing, directing and controlling. Whereas relating to operational functions, one of which is about recruitment is obtaining the right number and type of employees to occupy a position, especially related to the selection and placement concerning the quality and number of employees, while the selection and placement involves selecting and attracting employees according to their competence and expertise.

The first strategy is to empower all existing components for the creation of the vision and mission of BPBD of Garut which is to reduce the risk of disaster. It means that existing 
employees both permanent and honorary employees are utilized in order to support the main tasks of BPBD of Garut.

The second strategy is to empower community participation by forming forums or social organizations. This suggestion has been implemented by BPBD and researchers conducted observatory participants as resource persons in the formation of disaster resilient village organizations. Until this dissertation is held accountable in front of the board of examiners the researchers have formed 3 disaster resilient villages and will continue until the district of Garut becomes a disaster resilient district.

4.8. Leadership

Organizational goals can be achieved well requires an effective leader that is high leader in combining two dimensions, namely task-oriented leadership and relationshiporiented leadership. Effective leadership can carry out management functions properly including carrying out good planning, utilizing cooperation with employees to achieve organizational goals and carry out activities in the office environment optimally.

The strategies that can be applied are:

The first strategy, as a leader of an organization that requires speed and accuracy in action, the leader of BPBD must be an energetic person who has the desire to progress and wants to innovate.

The second strategy, The second strategy, a leader in the management is a decision maker, wise, always trie to consider the result of the settlement of the problem, formulate problems including finding a solution. It means that decision making must be based on experience, in-depth discussion, brainstorming, applying the principles that have been agreed upon. In addition to this, information collection should be supportive on issues accurately..

The third strategy, BPBD leader is a person who has the personal qualities that describe their characteristics and traits that stand out on himself a leader, and able to provide the distribution of decision-making power within the organization.

The fourth strategy is to be a leader regarding all aspects related to the decision making process in planning, organizing and monitoring. Supervision of functions that are no less important is that the habits of a group also influence the behavior of a leader because somehow the culture of a leader will influence the decision making. 
The fifth strategy, the leader should give a good example to his subordinates, because it will be used as a role model in carrying out his daily tasks, in addition to that the assertiveness of a leader in carrying out the task is needed not to mean fierce but firm in applying the rules, also discipline because employees must be disciplined in doing the task on time.

\subsection{Communication}

Communication is an implicit thing in the function of managerial orders and the principle of structural hierarchy. In general, employees are aware of the role of informal communication in relation to the problem of adding formal hierarchical channels, communication as a goal and desire to act, communication makes the organization's cooperative system more dynamic and connects the organization's goals with all the people involved in it. Communication techniques that are considered as oral language that is conveyed by word of mouth and written are not only needed to achieve organizational goals but also important things in organizations to get to know each other between employees in carrying out tasks to be smooth and exchange ideas.

The strategy adopted is: The first strategy is to realize the form of delivery of information tailored to the capacity and ability of an employee to absorb information and data received.

The second strategy: effective communication will be followed up by employees by taking steps in accordance with their respective functions, in principle communication that is expected to have been built properly between leaders and subordinates runs smoothly especially those related to the implementation of tasks are always informed of the materials received and communicated with all staff in the $\mathrm{BPBD}$, because they want the best results in disaster management.

The third strategy is to collect information conveyed from the field. Because the information that comes from the executor and the field is very necessary for disaster management accompanied by technological advances in information systems using computers as a means to process data more accurately and for certain for decision making. Besides, disaster management requires fast and appropriate handling so that the development of this technology can be utilized for disaster management. 


\subsection{Managerial Structure}

Realizing the integration of disaster management organizations, because the organizational structure of work procedures has explained that each organization has a main task and function regulated in a Decree of the Regent or Regional Regulation concerning the organizational structure of disaster management agencies. Each organization has the authority and responsibility that must be carried out and accounted for tasks.

The Head of the Agency as the top manager in the organizational environment decides in terms of strategic planning, which is related to the coordination and regulation of staffing issues for the smooth implementation of the duties of the head of the body assisted by a person who has the task of taking care of correspondence, guidance and supervision in the field of staffing.

The secretary has a strategic function for the organization. In terms of position, the secretary is a leader trust, the secretary knows everything related to the work of the leader, as a leader assistant or trustee of the leader, the secretary must have the ability to assist the leader in completing tasks and the secretary knows the characteristics and desires of the leader, so that a leader will not hesitate to give confidence to the secretary to do all his duties.

Strategies related to managerial functions:

The first strategy, make a standard operational procedure for the structure before, during and after a disaster occurs, because each situation requires a different structure.

The second strategy, during the emergency response, it is better for the managerial structure to prioritize the command and control functions. The most appropriate persons in emergency response conditions and the conditions that require the right decision making are personnel who are already trained in this case, namely members of the Indonesian National Army.

\subsection{The Change in "Rules of the Game".}

Strategy adopted: The first rule of action implemented in disaster management is from the economic and political system. To repair an economic system that is damaged or destroyed due to a disaster and to restore the community's economy by repairing facilities and infrastructure such as: damaged roads, rice fields affected by landslides or floods, 
buildings or other structures to be repaired so that the people's economy and activities return to normal even though it takes time and money.

The second strategy, by increasing the role of the government to handle crosssectorally, how the government responds to changes that occur due to disasters if it is not fundamental and damaging the economic order, and the existing economic system continues to run.

The third strategy, although all policies are political products, in terms of disasters, political policies do not need to be changed because actually disasters do not change the political system or order but the rules in politics for disaster management are government policies in favor of the community to respond to disasters that is expected by disaster society.

\subsection{Changes to Policies and Rule of Laws}

The demand for the role of the bureaucracy as a neutral administrative tool turns out in practice the government has become an inefficient and unprofessional institution despite a shift from the traditional perspective of public administration to the paradigm of public administration that does not encourage itself to a bureaucratic behavior, and public services in the field of disaster authority that is not regulated in certain laws or policies is required. Of course, in carrying out its duties and functions requires a legal basis for action. The strategies taken are:

The First Strategy, The policies that have been set can encourage government participation in optimally managing disasters and with the existence of these provisions can be implemented and implemented by the community and siding with the community, for this reason it is necessary for the government's creativity in managing disasters..

The Second Strategy, Immediately make a law regarding the handling of a significant deal with the Cimanuk River where the Cimanuk River currently has become a dirty and shallow river and in relatively short time can cause a massive flooding in the Garut region as happened in 2016 ago.

\subsection{Refomation of Institutional System}

The current institutional that has been formed which refers to the law on institutions actually refers to the regulation. In principle, with the formation of institutions tailored to the conditions and needs of the community for disaster management filled with employees 
who have the ability in their respective fields but have not been matched with their competencies and not in accordance with the needs of the institution.

The first strategy taken is: The need for qualified employees in accordance with the needs, because there is a shift in the needs of employees who had been an employee in the area of the safety zone. This means that if it is in accordance with the field of education, then the employee is safe while the current acceptance of employees is paying attention to the competencies or expertise possessed by each employee.

The second strategy. Based on an interesting thing that researchers found in research and interviews regarding institutional reform, it was implied from several sources that restructuring is something that can be categorized as something that can currently and reasonably do. And there are proposals to change the function of the organization that is currently under local government to be local, changed to a vertical organization where all coordination and activities and policies are centralized from the center in this case directly under the Badan Nasional Penanggulangan Bencana (BNPB).

The University of Wisconsin defines disaster management as "the range of activities designed to maintain control over disaster and emergency situation and to provide a framework for helping at-risk persons to avoid or recover from the impact of disaster. Disaster management deals with situation that occurs prior to, during, and after the disaster.

In principle, management is carried out before a disaster occurs, not during and after a disaster strike. The goals of good disaster management are: avoiding losses to individuals, communities, or countries through early action (before a disaster occurs), minimizing losses to individuals, communities, or the State. The effectiveness of this activity is carried out before the disaster occurs, minimizing the suffering carried by individuals and communities affected by the disaster, so that they can survive and restore optimism and confidence and improve conditions (rehabilitation) in the form of infrastructure improvements such as housing, roads, electricity, water supply, communication facilities, so that the people's economic turnarounds roll back and rise as before. The principle of disaster management is how to overcome human limitations in predicting and dealing with disasters which are then outlined in strategies and policies in anticipating, preventing and managing disasters. Mitigation policy is a long-term policy, not a short-term policy and temporary. Nor is it a partial and sporadic approach that results in a stand-alone policy 
Badan Penanggulangan Bencana Daerah Kabupaten of Garut (BPBD) is an agency under the Garut District government that has the main task of overcome disasters with a vision to reduce the risks that occur to the society. With a variety of phenomena and findings in the field, there are so many things that must be observed and implemented by BPBD of Garut in increasing its capacity as an institution that has very heavy main duties.

Disaster management institution, especially BPBD of Garut, in accordance with the law still have weaknesses. The weakness is that in terms of individual, organization and system.

From the individual side where employees in the BPBD environment according to Regional Regulations only amounted to 38 people. This made the BPBD as the frontline in disaster management in Garut encounter various obstacles faced by the very wide range of Garut regency control.

Regarding the organization, BPBD should be an organization that is ready to move at any time and a reliable control command 24 hours and 7 days a week, but the reality of the research results is different. In line with organization and individual also related to the system where the BPBD is still a horizontal organization under the control of the regional government, the obstacles that occur are still too complicated, especially related to the issue of operational funds.

Such institutional concepts contain weaknesses which greatly affect the effectiveness of these institutions. According to researchers, disaster management agencies must implement an adhock system, especially during an emergency response or create a position that allows a chief of Kodim staff to become the secretary of a disaster management agency even though it is an exofficio.

Researchers in the discussion recommend that disaster agencies must be vertical. The fact is that the head of the National Disaster Management Agency, is a Two Star High Officer, in the future this organization is vertical, meaning that if the organization is vertical then the head of the BNPB in the Province is held by a high ranking officer of the rank of one star or concurrently held by regional military officers.

Furthermore, the BNPB Chief in the district / city is also held by a military officer with the rank of Lieutenant Colonel or concurrently by a regional military officer in that place. 


\section{Conclusion}

The researchers conclude that the inhibiting factors for strengthening the institutional capacity of the Garut District disaster management agency so that it has not been effective are as follows::

a. Development Of Human Resources consisting of indicators: There is no training on disaster in the BPBD environment. The provision of salary or wages depends on the Regional Budget. In emergency conditions there has been no change in the conditions of work in emergencies and general conditions. The existing work environment is not well organized. The current recruitment system is only a quantity fulfillment not about quality.

b. Strengthening organization consisting of indicators: Incentive systems are not specifically regulated for organizations that have high escalations such as BPBD. Existing personnel are so limited that the head of BPBD has difficulty utilizing these personnel. The absence of functional staff, who can become professional staff in carrying out tasks..

c. Reformation of institution consisting of indicators: there is no change in the rules of the game in emergency response conditions. The absence of changes in policy and rule of law in dealing with emergency response conditions. Conducted when a disaster has occurred, it should be done before a disaster.

Researchers suggest 3 major parts of strategies that can be undertaken in order to strengthen the institutional capacity of BPBD in Garut District effectively:

a. In connection with strengthening human resources, the strategy found by researchers is in terms of training to carry out routine exercises with relevant agencies at least once every 6 months. Then, for recruitment to be recruited professionals who are experts in the field of disaster.

b. Related to organizational strengthening, the strategy found by researchers is that payroll must be timely. An employee with very little quantity in order to be given the opportunity to continue schooling to increase their knowledge of disaster problems, and immediately raise the status of contract workers to become employees.

c. Related to the system, the strategy that the researchers found was that the BPBD organization needed some significant changes, where the BPBD had to be a vertical organization to make it easier to control.. 


\section{References}

\section{Elektronik Soure}

J. W. Creswell, Research Design_Qualitative, Quantitative, and Mixed Methods. Thousand Oaks, California: SAGE Publications, Inc.

A. B. Susanto, “Disaster management di negeri rawan bencana : sebuah pendekatan strategic management / A.B. Susanto," The Jakarta Consulting Group \& Eka Tjipta Foundation, 2006. .

NORMAN UPHOFF, Local Institutions and Participation for Sustainable Development, GATEKEEPER. Kennedy Hil,NEW YORK: International Institute for Environment and Development.

Fred Luthans, "Perilaku Organisasi," he McGraw-Hill Companies, Inc, 2012. .

Peraturann Buapati Kabupaten Garut No.7 Tahun 2011 PEMBENTUKAN DAN SUSUNAN ORGANISASI BADAN PENANGGULANGAN BENCANA DAERAH KABUPATEN GARUT. Pemkab Garut, 2011.

Merilee S. Grindle, Politics and policy implementation in the third world, 4880 ed. Princeton University Press, 2017.

C. P. Kurniawati, "KAJIAN PERMASALAHAN KEBIJAKAN PENETAPAN STATUS BENCANA, KELEMBAGAAN BPBD, DAN PENGELOLAAN BANTUAN PASCA TERBITNYA UU NOMOR 24 TAHUN 2007," JURNAL TATA KELOLA \& AKUNTABILITAS KEUANGAN NEGARA, vol. 1, no. PERMASALAHAN KEBIJAKAN PENETAPAN STATUS BENCANA, hal. 12, 2014.

I. Agusta, "Penguatan kelembagaan untuk penguatan kawasan Agropolitan," no. kelembagaan, hal. 32 .

mohamad C. Ulum, Governance and capacity building of handling the flood issues in Bojonegoro Municipality, Indonesia. bojonegoro: Prince of Songkla University, 2013.

M. S. G. M E Hilderbrand, "Building Sustainable Capacity in the Public Sector," 1997. [Daring]. Tersedia pada: https://gsdrc.org/document-library/building-sustainablecapacity-in-the-public-sector-what-can-be-done/. [Diakses: 08-Okt-2019].

L. J. Moleong, Metodologi Penelitian Kualitatif (Edisi Revisi), Revisi. Bandung: PT Remaja Rosdakarya, 2005. 
Merilee S. Grindle, Decentralization, Democratization, and the Promise of Good Governance. Princeton University Press, 2007.

Undang-undang 34 Tahun 2004 Tentang TNI. 2004.

kemendagri, Permendagri 46 Tahun 2008 Pedoman Organisasi dan Tata Kerja Organisasi. Jakarta: kemendagri RI, 2008.

\section{Non elektrfonik Source}

Abdulah,Irwan.' Dialektika Natur, Kultur dan Struktur:Analisis Konteks, Proses, dan Ranah dalam Konstruksi Bencana' Pidato Pengukuhan Guru Besar dalam Antropologi Universitas Gadjah Mada,Yogyakarta, tanggal 13 Nopember 2006

Carolyn Ridenour and Isadore Newman “ Mixed Mthods Research" Southern Illionis USA 2008 